\title{
Metal resistance or tolerance? Acidophiles confront high metal loads via both abiotic and biotic mechanisms
}

\author{
Mark Dopson ${ }^{1}$, Francisco J. Ossandon ${ }^{2}$, Lars Lövgren ${ }^{3}$ and David S. Holmes ${ }^{2}$ \\ Department of Biology and Environmental Sciences and Centre for Ecology and Evolution in Microbial Model Systems, Linnaeus University, \\ Kalmar, Sweden \\ ${ }^{2}$ Center for Bioinformatics and Genome Biology, Fundacion Ciencia y Vida and Departamento Ciencias Biologicas, Facultad de Ciencias Biológicas, Universidad \\ Andrés Bello, Santiago, Chile \\ ${ }^{3}$ Department of Chemistry, Umeå University, Umeå, Sweden
}

\section{Edited by:}

Axel Schippers, Federal Institute for Geosciences and Natural Resources, Germany

\section{Reviewed by:}

Johannes Gescher, Karlsruhe Institute of Technology, Germany

Sabrina Hedrich, Federal Institute for Geosciences and Natural Resources, Germany

\section{*Correspondence:}

Mark Dopson, Department of Biology and Environmental Sciences and Centre for Ecology and Evolution in Microbial Model Systems, Linnaeus University, Landgången 3, 39182 Kalmar, Sweden

e-mail:mark.dopson@Inu.se
All metals are toxic at high concentrations and consequently their intracellular concentrations must be regulated. Extremely acidophilic microorganisms have an optimum growth of $\mathrm{pH}<3$ and proliferate in natural and anthropogenic low pH environments. Some acidophiles are involved in the catalysis of sulfide mineral dissolution, resulting in high concentrations of metals in solution. Acidophiles are often described as highly metal resistant via mechanisms such as multiple and/or more efficient active resistance systems than are present in neutrophiles. However, this is not the case for all acidophiles and we contend that their growth in high metal concentrations is partially due to an intrinsic tolerance as a consequence of the environment in which they live. In this perspective, we highlight metal tolerance via complexation of free metals by sulfate ions and passive tolerance to metal influx via an internal positive cytoplasmic transmembrane potential. These tolerance mechanisms have been largely ignored in past studies of acidophile growth in the presence of metals and should be taken into account.

Keywords: metal, acidophile, resistance, tolerance, homeostasis, biomining

\section{INTRODUCTION}

Microorganisms utilize metals as structural components of biomolecules, as cofactors in reversible oxidation/reduction reactions and in electron transfer chains during energy conservation. However, metals can become toxic if their intracellular concentrations are too high. Therefore, metal (and metalloid) homeostasis and resistance systems are required to maintain optimal intracellular metal concentrations (Nies and Silver, 2007).

Acidophilic microorganisms (optimal growth $\mathrm{pH}<3$ ) often grow in metal rich environments such as acid sulfate soils containing iron sulfides (Wu et al., 2013) and milieus associated with metal sulfide mining (Dopson and Johnson, 2012). As many metals are more soluble at acidic $\mathrm{pH}$, acidophiles are typically exposed to high metal concentrations and can survive in $\leq 1000$-fold higher amounts than neutrophilic microorganisms (Dopson et al., 2003). As a consequence, they are often described as highly metal resistant and that they have multiple and/or more efficient active resistance systems than are present in neutrophiles. However, some acidophiles do not appear to have more metal resistance genes and we contend that their growth in high metal concentrations is partially due to an intrinsic tolerance as a consequence of the environment in which they live.

\section{ACIDOPHILE METAL RESISTANCE OR TOLERANCE?}

Acidophile metal resistance strategies do not fully explain why they are able to grow in solution with very high concentrations of metals. Below we describe largely ignored acidophile metal tolerance systems such as complexation of free metals by sulfate ions and passive tolerance to metal influx via an internal positive cytoplasmic transmembrane potential.

\section{METAL SPECIATION AND ACIDOPHILES}

In modern ecotoxicology, it is acknowledged that the distribution of metals between different chemical species (the speciation) must be accounted for when their ecotoxic effects are assessed (Christiansen et al., 2011) and that the free ion is the most toxic form of the metal (Di Toro et al., 2001). Acidophilic microorganisms often grow in environments containing high concentrations of sulfate ions that can complex metal cations at acidic $\mathrm{pH}$. Therefore, the concentrations of free ions that can enter the cytoplasm and consequently challenge acidophiles are significantly lower than the total concentration of the metal. As a consequence, it is possible that extreme metal tolerance in acidophiles is partially a function of free metal ion complexation by sulfate that precludes the metal ion entry into the cell. The percentages of free metal ion for $\mathrm{Cu}^{2+}, \mathrm{Ni}^{2+}$, and $\mathrm{Zn}^{2+}$ were between 60 to $70 \%$ of the $200 \mathrm{mM}$ metal ion calculated for each case (i.e., 60 to $80 \mathrm{mM}$ of the metals were bound as sulfate ions and could not enter the cell; Figure 1). This was correct for a $\mathrm{pH}$ range from 1.0 to 3.5 that is typical for acidophilic microorganisms. When higher metal concentrations are present, the sulfate concentration would also likely be higher (metal sulfide dissolution also generates sulfate ions from oxidation of the sulfur moiety). An example calculated for an extreme acid mine drainage stream is at Iron Mountain, California that has $5 \mathrm{mM} \mathrm{Cu},<1 \mathrm{mM} \mathrm{Ni}, 31 \mathrm{mM} \mathrm{Zn}, 324 \mathrm{mM} \mathrm{Fe}^{2+}$, and $39 \mathrm{mM}$ $\mathrm{Fe}^{3+}$ that may be complexed by $1229 \mathrm{mM}$ sulfate (Nordstrom 


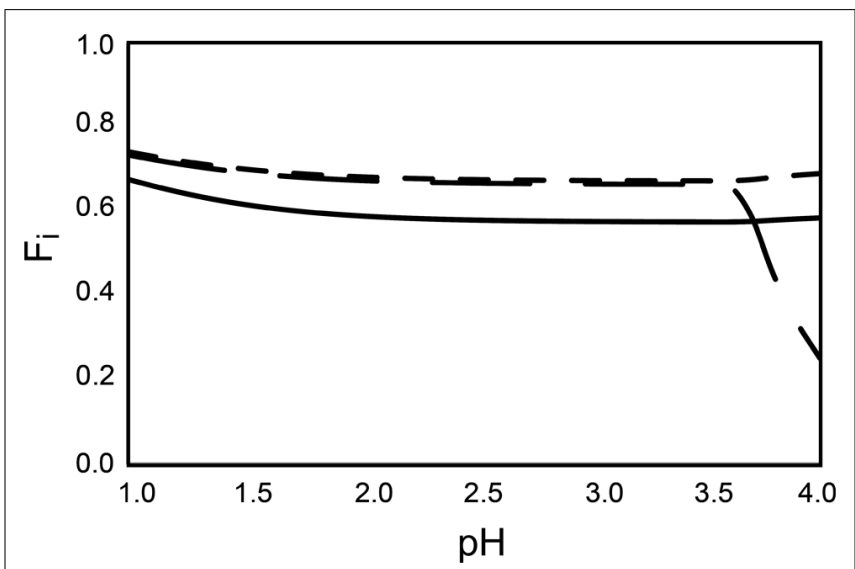

FIGURE 1 |The fraction of total free metal ion (Fi) for each of the metals. The amount of free metal ion (Fi) of $\mathrm{Zn}^{2+}$ (solid line), $\mathrm{Cu}^{2+}$ (long dashes), and $\mathrm{Ni}^{2}+$ (short dashes) denoted as a fraction (100\% free ion defined as 1.0) of total metal ion present in each of the species. The metal concentrations are calculated for systems with $200 \mathrm{mM}$ of the respective metals, $285 \mathrm{mM} \mathrm{SO}_{4}{ }^{2-}$, and $50 \mathrm{mM} \mathrm{Fe}^{2+}$. The calculations are made using the computer code WinSGW (Karlsson and Lindgren, 2006) based on the speciation code Solgaswater (Eriksson, 1979). Equilibrium constants are collected from the equilibrium database Hydra/Medusa (Puigdomenech, 2004).

and Alpers, 1999). Modeling of the metal speciation for this case showed $>98 \%$ of all the metals other than $\mathrm{Fe}^{2+}$ were complexed by sulfate (Figure 2). Complexation of free metal by sulfate highlights the necessity of taking the speciation into account when metal tolerance is examined for acidophiles. This has been shown for $\mathrm{Zn}^{2+}$ toxicity to Acidithiobacillus caldus, Acidimicrobium ferrooxidans, and Ferroplasma acidarmanus (Mangold et al., 2012).

\section{METAL TOLERANCE CONFERRED BY pH HOMEOSTASIS AND pH OPTIMA}

Cytoplasmic membranes have three electrostatic potentials: the transmembrane potential, the dipole potential, and the surface potential (Wang, 2012). Acidophiles have an inside positive cytoplasmic transmembrane potential (neutrophiles have an inside negative potential) that is reinforced by the dipole potential. This helps to maintain $\mathrm{pH}$ homeostasis as $\mathrm{H}^{+}$must travel "uphill” against a chemiosmotic gradient to enter the cytoplasm (Baker-Austin and Dopson, 2007; Slonczewski et al., 2009). The transmembrane and dipole potentials also provide a hindrance to metal cation influx. If this barrier is sufficiently strong then only a portion of the available free metal ion will penetrate the cell and cause a toxicity response. This potential method of intrinsic metal tolerance may have conferred the ability to withstand high metal concentrations before the evolution of more complex pumps.

A further effect of acidophile optimum growth $\mathrm{pH}$ is increased competition between cations and protons for cell surface binding sites (Heijerick et al., 2002). This is supported by growth experiments with At. caldus where $\mathrm{Zn}$ toxicity decreased at lower $\mathrm{pH}$ values (Stefanie Mangold, Ph.D. thesis, Umeå University), potentially as less metal enters the cytoplasm at acidic $\mathrm{pH}$. The possibility that only a small fraction of extracellular metals cross the cell membrane is supported by the small increase in intracellular $\mathrm{Zn}$

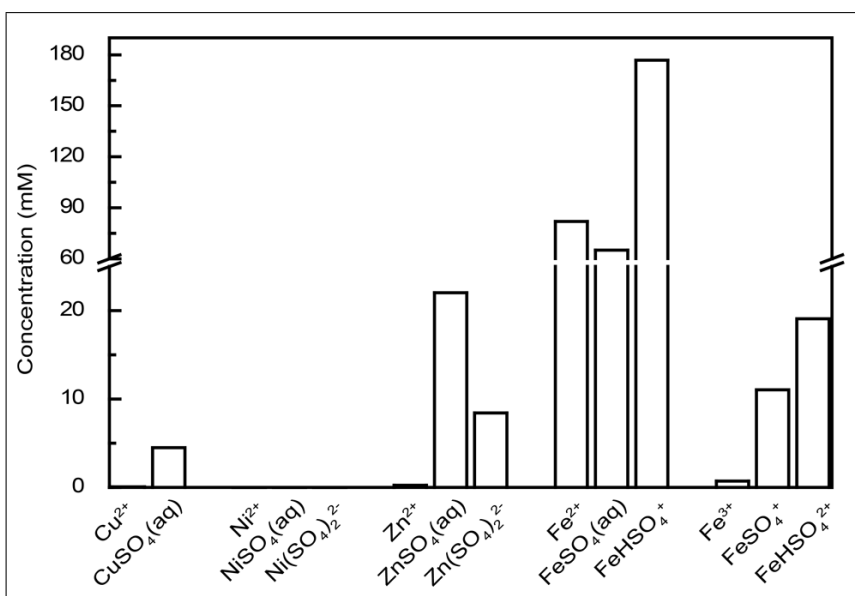

FIGURE 2 | The aqueous metal speciation in Iron Mountain, California. The concentrations of free metal ions and metal speciation by sulfate are calculated assuming the composition of sample 90WA103 from the Richmond Mine, Iron Mountain (Nordstrom and Alpers, 1999) at pH 0.48. A temperature of $25^{\circ} \mathrm{C}$ is assumed in the calculations and other metal concentrations are considered to be zero.

observed in resting cells of At. caldus, Ac. ferrooxidans, and F. acidarmanus and a lack of a general stress response when these species are cultured with external concentrations up to $200 \mathrm{mM} \mathrm{Zn}$ (Mangold et al., 2012). However, it is not supported by the detection of stress proteins in the presence of more toxic metals such as $\mathrm{Cu}$ in F. acidarmanus (Baker-Austin et al., 2005) and Metallosphaera sedula (Maezato et al., 2012); Cu and Cd in Sulfolobus metallicus (Orell et al., 2013); $\mathrm{Fe}^{2+}$ in F. acidarmanus (Dopson et al., 2005); and in the natural Iron Mountain acid mine drainage community that is challenged by very high metal concentrations (Ram et al., 2005).

\section{HIGHER FREOUENCY OF KNOWN METAL RESISTANCE SYSTEMS}

A further method by which acidophiles are more metal resistant is that their genomes contain genes encoding for more metal resistance systems than in neutrophiles. An example of a multiple metal resistance systems is the ATPase and Cus systems encoded on a gene island in Acidithiobacillus ferrooxidans ATCC 53993 that is not present on the type strain that may explain its higher $\mathrm{Cu}$ resistance (Orellana and Jerez, 2011). To test if acidophiles have a higher frequency of metal resistance systems, the percentage of genes related to $\mathrm{Zn}$ and $\mathrm{Cu}$ resistance within the total number of genes encoded in the respected genomes were separately calculated for 23 neutrophile and 21 acidophile genomes. The genomes were chosen based on three criteria: (1) the genome sequences were publicly available at the time that the analysis was initiated; (2) they were derived from different branches of the phylogenetic tree and include Bacteria and Archaea; and (3) the sequences were derived from organisms in which the associated metadata was available (e.g., phylogeny, temperature, and $\mathrm{pH}$ optima). The results for both $\mathrm{Zn}$ and $\mathrm{Cu}$ showed no significant difference calculated as the average percentage of genes $\pm \mathrm{SD}$ for the acidophiles compared to the neutrophiles $(0.28 \% \pm 0.28$ compared to $0.17 \% \pm 0.14$, respectively, for the zinc resistance gene analysis and $0.25 \% \pm 0.23$ 
compared to $0.15 \% \pm 0.12$, respectively, for copper resistance). A further pairwise $t$-test comparing $\mathrm{Zn}$ and $\mathrm{Cu}$ resistance genes between acidophiles and neutrophiles based upon the phylogeny of the species also showed no significant difference for both $\mathrm{Zn}$ $(p=0.49)$ and $\mathrm{Cu}(p=0.37)$. Although the difference between the acidophiles and neutrophiles is insignificant, it is interesting that the 7 acidophile genomes with the highest percentage of $\mathrm{Zn}$ resistance genes include all of the analyzed Acidithiobacillus spp. and Leptospirillum ferriphilum that are commonly identified in biomining environments and therefore challenged by high metal concentrations (Okibe et al., 2003; Dopson and Lindström, 2004). However, not all common biomining microorganisms have higher levels of $\mathrm{Zn}$ resistance genes as the highly metal resistant species; F. acidarmanus (Dopson et al., 2004) only contains $0.05 \%$ of genes annotated as related to $\mathrm{Zn}$ resistance. A possibility is that species capable of growth at higher $\mathrm{pH}$ values, such as the Acidithiobacillus spp. (Mielke et al., 2003), have a lower competition between protons and cations for binding sites (discussed above) that is compensated for by more resistance genes. In support of this explanation is that the archaea, and in particular those species capable of growth close to $\mathrm{pH} 0$, tend to have lower percentages of $\mathrm{Zn}$ resistance genes than bacteria. The higher number of acidophile genes related to $\mathrm{Cu}$ resistance may be due to its higher availability as a free ion at acidic $\mathrm{pH}$ compared to neutral conditions. It is not known if these trends also hold for other metals than $\mathrm{Zn}$ and $\mathrm{Cu}$ and further studies are needed.

\section{OXYANIONS, AN EXCEPTION TO THE RULE?}

Arsenic is predominantly present in biomining environments as the metalloids, arsenate $\left(\mathrm{AsO}_{4}{ }^{3-}\right)$ and arsenite $\left(\mathrm{AsO}_{3}{ }^{3-}\right.$ at neutral $\mathrm{pH}$ and $\mathrm{AsOH}_{3}$ at acidic $\left.\mathrm{pH}\right)$. Therefore, the intrinsic acidophile cation tolerance systems described in this review would not aid in arsenic resistance. This may at least partially explain why acidophiles are $<100$-fold more resistant to arsenic than neutrophiles when they are up to 1000 -fold more resistant than neutrophiles to metal cations (Dopson et al., 2003). This would also be true for other oxyanions, such as for molybdenum and vanadium.

\section{CONCLUSION}

It is very difficult to compare resistance between microbial species as metal toxicity is dependent on its biological availability (free ion toxicity), the solution chemistry, and the variable toxicity of metal ions to specific cellular functions. Acidophiles have a variety of intrinsic and active metal resistance systems that likely combine to permit their growth in very high metal concentrations. Also, it cannot be ruled out that novel, previously undetected resistance systems are present that contribute to active acidophile metal resistance. The potential contribution of abiotic factors such as metal speciation combined with metal tolerance afforded by the internal positive transmembrane and dipole potentials, and competition for binding sites to acidophile metal resistance has been largely overlooked. In the future, these factors should also be taken into account when assessing acidophile growth in high metal loads.

\section{ACKNOWLEDGMENTS}

Mark Dopson acknowledges the Swedish Research Council (Vetenskapsradet contract number 621-2007-3537) and Cost action CM0902 - Molecular machineries for ion translocation across biomembranes for funding research included in this review. David Holmes acknowledges support from Fondecyt Grant 1130683.

\section{REFERENCES}

Baker-Austin, C., and Dopson, M. (2007). Life in acid: pH homeostasis in acidophiles. Trends Microbiol. 15, 165-171. doi: 10.1016/j.tim.2007.02.005

Baker-Austin, C., Dopson, M., Wexler, M., Sawers, G., and Bond, P. L. (2005). Molecular insight into extreme copper resistance in the extremophilic archaeon "Ferroplasma acidarmanus" Fer1. Microbiology 151, 2637-2646. doi: 10.1099/mic.0.28076-0

Christiansen, K. S., Holm, P. E., Borggaard, O. K., and Hauschild, M. Z. (2011). Addressing speciation in the effect factor for characterisation of freshwater ecotoxicity - the case of copper. Int. J. Life Cycle Assess. 16, 761-773. doi: 10.1007/s11367-011-0305-7

Di Toro, D. M., Allen, H. E., Bergman, H. L., Meyer, J. S., Paquin, P. R., and Santore, R. C. (2001). Biotic ligand model of the acute toxicity of metals. 1. Technical basis. Environ. Toxicol. Chem. 20, 2383-2396. doi: 10.1897/1551-5028(2001)0202. $0 . \mathrm{CO} ; 2$

Dopson, M., Baker-Austin, C., and Bond, P. L. (2005). Analysis of differential protein expression during growth states of Ferroplasma strains and insights into electron transport for iron oxidation. Microbiology 151, 4127-4137. doi: 10.1099/mic.0.28362-0

Dopson, M., Baker-Austin, C., Hind, A., Bowman, J. P., and Bond, P. L. (2004). Characterization of Ferroplasma isolates and Ferroplasma acidarmanus sp. nov., extreme acidophiles from acid mine drainage and industrial bioleaching environments. Appl. Environ. Microbiol. 70, 2079-2088. doi: 10.1128/AEM.70.4.2079-2088.2004

Dopson, M., Baker-Austin, C., Koppineedi, P. R., and Bond, P. L. (2003). Growth in sulfidic mineral environments: metal resistance mechanisms in acidophilic micro-organisms. Microbiology 149, 1959-1970. doi: 10.1099/mic.0. 26296-0

Dopson, M., and Johnson, D. B. (2012). Biodiversity, metabolism and applications of acidophilic sulfur- metabolizing micro-organisms. Environ. Microbiol. 14, 2620 2631. doi: 10.1111/j.1462-2920.2012.02749.x

Dopson, M., and Lindström, E. B. (2004). Analysis of community composition during moderately thermophilic bioleaching of pyrite, arsenical pyrite and chalcopyrite. Microb. Ecol. 48, 19-28. doi: 10.1007/s00248-0032028-1

Eriksson, G. (1979). An algorithm for the computation of aqueous multicomponent, multiphase equilibria. Anal. Chim. Acta 112, 375-383. doi: 10.1016/S0003-2670(01)85035-2

Heijerick, D. G., De Schamphelaere, K. A., and Janssen, C. R. (2002). Biotic ligand model development predicting $\mathrm{Zn}$ toxicity to the alga Pseudokirchneriella subcapitata: possibilities and limitations. Comp. Biochem. Physiol. C Toxicol. Pharmacol. 133, 207-218. doi: 10.1016/S1532-0456(02)00077-7

Karlsson, M., and Lindgren, J. (2006). WinSGW, a User Interface for SolGasWater. Available at: www.winsgw.se (accessed February 13, 2014).

Maezato, Y., Johnson, T., Mccarthy, S., Dana, K., and Blum, P. (2012). Metal resistance and lithoautotrophy in the extreme thermoacidophile Metallosphaera sedula. J. Bacteriol. 194, 6856-6863. doi: 10.1128/JB.01413-12

Mangold, S., Potrykus, J., Björn, E., Lövgren, L., and Dopson, M. (2012). Extreme zinc tolerance in acidophilic microorganisms from the bacterial and archaeal domains. Extremophiles 17, 75-85. doi: 10.1007/s00792-012-0495-3

Mielke, R. E., Pace, D. L., Porter, T., and Southam, G. (2003). A critical stage in the formation of acid mine drainage: colonization of pyrite by Acidithiobacillus ferrooxidans under pH-neutral conditions. Geobiology 1, 81-90. doi: 10.1046/j.1472-4669.2003.00005.x

Nies, D. H., and Silver, S. (eds). (2007). Molecular Microbiology of Heavy Metals. New York: Springer. doi: 10.1007/978-3-540-69771-8

Nordstrom, D. K., and Alpers, C. N. (1999). Negative pH, efflorescent mineralogy, and consequences for environmental restoration at the iron mountain superfund site, California. Proc. Natl. Acad. Sci. U.S.A. 96, 3455-3462. doi: 10.1073/pnas.96.7.3455 
Okibe, N., Gericke, M., Hallberg, K. B., and Johnson, D. B. (2003). Enumeration and characterization of acidophilic microorganisms isolated from a pilot plant stirred-tank bioleaching operation. Appl. Environ. Microbiol. 69, 1936-1943. doi: 10.1128/AEM.69.4.1936-1943.2003

Orell, A., Remonsellez, F., Arancibia, R., and Jerez, C. A. (2013). Molecular characterization of copper and cadmium resistance determinants in the biomining thermoacidophilic archaeon Sulfolobus metallicus. Archaea 2013, 289236. doi: $10.1155 / 2013 / 289236$

Orellana, L. H., and Jerez, C. A. (2011). A genomic island provides Acidithiobacillus ferrooxidans ATCC 53993 additional copper resistance: a possible competitive advantage. Appl. Microbiol. Biotechnol. 92, 761-767. doi: 10.1007/s00253-0113494-x

Puigdomenech, I. (2004). Hydra/Medusa Chemical Equilibrium Database and Plotting Software. Stockholm: KTH - Royal Institute of Technology.

Ram, R. J., Verberkmoes, N. C., Thelen, M. P., Tyson, G. W., Baker, B. J., Blake, R. C., et al. (2005). Community proteomics of a natural microbial biofilm. Science 308, 1915-1920. doi: 10.1126/science. 1109070

Slonczewski, J. L., Fujisawa, M., Dopson, M., and Krulwich, T. A. (2009). Cytoplasmic $\mathrm{pH}$ measurement and homeostasis in bacteria and archaea. Adv. Microb. Physiol. 55, 1-79. doi: 10.1016/S0065-2911(09)05501-5

Wang, L. (2012). Measurements and implications of the membrane dipole potential. Annu. Rev. Biochem. 81, 615-635. doi: 10.1146/annurev-biochem-070110123033
Wu, X., Wong, Z. L., Sten, P., Engblom, S., Österholm, P., and Dopson, M. (2013) Microbial community potentially responsible for acid and metal release from an Ostrobothnian acid sulfate soil. FEMS Microbiol. Ecol. 84, 555-563. doi: $10.1111 / 1574-6941.12084$

Conflict of Interest Statement: The authors declare that the research was conducted in the absence of any commercial or financial relationships that could be construed as a potential conflict of interest.

Received: 10 February 2014; accepted: 24 March 2014; published online: 09 April 2014. Citation: Dopson M, Ossandon FJ, Lövgren L and Holmes DS (2014) Metal resistance or tolerance? Acidophiles confront high metal loads via both abiotic and biotic mechanisms. Front. Microbiol. 5:157. doi: 10.3389/fmicb.2014. 00157

This article was submitted to Extreme Microbiology, a section of the journal Frontiers in Microbiology.

Copyright (c) 2014 Dopson, Ossandon, Lövgren and Holmes. This is an openaccess article distributed under the terms of the Creative Commons Attribution License (CC BY). The use, distribution or reproduction in other forums is permitted, provided the original author(s) or licensor are credited and that the original publication in this journal is cited, in accordance with accepted academic practice. No use, distribution or reproduction is permitted which does not comply with these terms. 